\title{
Cibercultura e educação: a comunicação na sala de aula presencial e online*
}

\section{RESUMO}

Este texto vem mostrar que na cibercultura as práticas de ensino e de aprendizagem deparam-se com o contexto sociotécnico do computador e da Internet onde emergem práticas comunicacionais que liberam o processo comunicacional do imperativo unidirecional dos meios de massa (impresso, cinema, rádio e TV) e oportunizam a multidirecionalidade em rede. Para isso, parte dos estudos da cibercultura e traz sugestões para a construção de uma agenda comunicacional capaz de expressar a dinâmica que associa emissão e recepção como pólos antagônicos e complementares na co-criação da comunicação e do conhecimento.

\section{PALAVRAS-CHAVE}

cibercultura

educação

docência e aprendizagem presencial e online

\begin{abstract}
This conference argues that teaching and learning practices in a cyberculture are faced with a sociotechnical context based on the computer and Internet in which communication practices are emerging that release the communication process from the unidirectional imperative of the mass media (the printed media, cinema, radio and $T V$ ) and provide the opportunity for network-based multidirectionality. To this end, the conference starts by examining studies of cyberculture and makes a number of suggestions regarding the development of a communication program that can embody the dynamics that bring together transmission and reception as opposite and complementary poles in the co-creation of communication and knowledge.
\end{abstract}

\section{KEY WORDS}

cyberculture

education

classroom-based and online teaching and learning

\author{
Marco Silva \\ Professor da Universidade Estácio de Sá - RJ - UERJ/ RJ/ BR \\ marcoparangole@uol.com.br
}

Em grande parte dos cursos via Internet prevalece o modelo comunicacional centrado na transmissão de informações. Os ambientes "virtuais" de aprendizagem continuam estáticos, ainda centrados na distribuição de dados desprovidos de mecanismos de interatividade, de criação colaborativa e de aprendizagem construída. Muito já se questionou a prática pedagógica baseada na transmissão para memorização e repetição, mas pouco se fez para modificá-la efetivamente. Doravante teremos mais do que a força da crítica mais veemente já feita. Teremos a exigência cognitiva e comunicacional das novas gerações que emergem com a cibercultura.

Na cibercultura a educação na modalidade "a distância", tradicionalmente baseada nos meios de massa (imprensa, rádio e TV), é cada vez mais online. A legislação oficial do MEC impulsiona amplamente a oferta da modalidade "não presencial". As universidades particulares ampliam largamente a oferta de disciplinas e cursos online com vistas no negócio promissor. A procura por cursos online aumenta surpreendentemente por causa da sua flexibilidade, mobilidade e atemporalidade. Este texto, fruto de pesquisas realizadas, vem mostrar que a dinâmica comunicacional da cibercultura e das interfaces de comunicação online entram em conflito com os fundamentos e práticas do ensino tradicional, em que se tem o professor responsável pela produção e pela transmissão do "conhecimento".

$\mathrm{Na}$ modalidade online professor permanece ainda tratando os aprendizes como recipientes de informação e não como agentes de colaboração, de compartilhamento e de co-criação, hábitos e comportamentos que se desenvolvem com a cibercultura. Neste contexto a "lógica da distribuição", própria dos meios de massa, subutiliza as potencialidades comunicacionais da $w e b$. Mesmo utilizando fóruns e e-mails, a interação é ainda muito pobre.

A partir da crítica ao modo de comunicação que prevalece na educação online, o texto sugere estratégias de organização e funcionamento da docência que permitem redefinir a atuação dos professores e dos alunos como agentes do processo de comunicação e de aprendizagem, em sintonia com a dinâmica comunicacional da cibercultura.

\section{0 cenário sociotécnico da cibercultura e perspectivas para a educação online}

A tela do computador online não é canal de recepção para o indivíduo solitário. Ela é campo de possibilidades para a ação do sujeito interagente que opera facilmente com outros interagentes a partir de imagens, sons e textos plásticos e dinâmicos em sua condição digital. $\mathrm{O}$ 
digital possui uma qualidade semiótica intrínseca definida matematicamente, em combinações numéricas de " 1 " e " 0 ". A existência imaterial da mensagem online confere aos interagentes a liberdade de manipular infinitamente os dados digitalizados, criando e recriando novas possibilidades de representação e de navegação, de acordo com as suas decisões em um campo de referências multidirecionadas.

Portanto, o computador online não é um meio de transmissão de informação como a televisão, mas espaço de adentramento e manipulação em janelas móveis, plásticas e abertas a múltiplas conexões entre conteúdos e interagentes geograficamente dispersos. Para além das interferências, manipulações e modificações nos conteúdos presentes na tela do computador off-line, os interagentes podem interagir realizando compartilhamentos e encontros de colaboração síncronos e assíncronos.

Assim entendido, o computador online renova a relação do sujeito com a imagem, com o texto, com o som, com o registro, com o conhecimento.

Ele permite o redimensionamento da mensagem, da emissão e da recepção para além da distribuição de pacotes de informação de A para B ou de A sobre B própria dos meios de massa tradicionalmente utilizados em educação a distância.

No contexto dos meios de massa, a mensagem é fechada, uma vez que a recepção está separada da produção. O emissor é um apresentador que atrai o receptor de maneira mais ou menos sedutora para o seu universo mental, seu imaginário, sua récita. E quanto ao receptor, seu estatuto nessa interação limita-se à assimilação passiva ou inquieta, mas sempre como recepção separada da emissão.

A lógica da transmissão em massa perde sua força no cenário sociotécnico que ganha forma a partir das transformações recentes do social e do tecnológico imbricados (Silva, 2006):

-Social. Há um novo espectador menos passivo diante da mensagem mais aberta à sua intervenção. Ele aprendeu com o controle remoto da TV, com o joystick do videogame e agora aprende como o mouse e com a tela tátil. Ele migra da tela da TV para a tela do computador conectado à Internet. É mais consciente das tentativas de programá-lo e mais capaz de esquivar-se delas. Evita acompanhar argumentos lineares que não permitem a sua interferência e lida facilmente com ambientes midiáticos que dependem do seu gesto instaurador que cria e alimenta a sua experiência comunicacional;

- Tecnológico. O computador conectado à Internet permite ao interagente criação e controle dos processos de informação e comunicação mediante ferramentas e interfaces de gestão. Diferindo profundamente da TV, enquanto máquina restritiva e centralizadora, porque baseada na transmissão de informações elaboradas por um centro de produção (sistema broadcast), o computador online apresenta-se como sistema aberto aos intera- gentes permitindo autoria e co-criação na troca de informações e na construção do conhecimento. Nesse cenário sociotécnico ocorre a transição da lógica informacional baseada no modelo "um-todos" (transmissão) para a lógica da comunicacional segundo a dinâmica "todos-todos" (interatividade). Uma modificação profunda no esquema clássico da informação baseado na ligação unilateral emissor-mensagem-receptor (Marchand, 1986).

- O emissor não emite mais no sentido que se entende habitualmente uma mensagem fechada. Ele oferece um leque de elementos e possibilidades à manipulação do receptor;

- A mensagem não é mais emitida, não é mais um mundo fechado, paralisado, imutável, intocável, sagrado, é um mundo aberto em rede, modificável na medida em que responde às solicitações daquele que a consulta;

- O receptor não está mais em posição de recepção clássica, é convidado à livre criação, e a mensagem ganha sentido sob sua intervenção.

Os princípios da interatividade podem ser encontrados em sua complexidade nas disposições técnicas do computador online. São três basicamente: a) participação-intervenção: participar não é apenas responder "sim" ou "não" ou escolher uma opção dada, supõe interferir no conteúdo da informação ou modificar a mensagem; b) bidirecionalidade-hibridação: a comunicação é produção conjunta da emissão e da recepção, é co-criação, os dois pólos codificam e decodificam; c) permutabilidade-potencialidade: a comunicação supõe múltiplas redes articulatórias de conexões e liberdade de trocas, associações e significações.

Estes fundamentos podem garantir o sentido não banalizado do conceito e inspirar o rompimento com a lógica da transmissão e abrir espaço para o exercício da participação genuína, isto é, participação sensório-corporal e semântica e não apenas mecânica (Silva, 2006).

Para Couchot (1997, p. 143), "a interatividade é o pão cada vez mais cotidiano de uma sociedade inteira". Seu conceito, se depurado da banalização mercadológica de praxe, exprime a disponibilização consciente de um plus comunicacional de modo expressamente complexo presente na mensagem e previsto pelo emissor, que abre ao receptor possibilidades de responder ao sistema de expressão, de dialogar e criar com ele.

No contexto da cibercultura, a interatividade manifesta-se nas práticas comunicacionais como e-mails, listas, blogs, videologs, jornalismo online, Wikipédia, Youtube, MSN Messenger, Orkut, chats, MP3 e novos empreendimentos que aglutinam grupos de interesse como cibercidades, games, softwares livres, ciberativismo, webarte, música eletrônica.

No ciberespaço cada sujeito pode adicionar, retirar e modificar conteúdos dessa estrutura; pode disparar informações e não somente receber, uma vez que o pólo da emissão está liberado; pode alimentar laços 
comunitários de troca de competências, de coletivização dos saberes, de construção colaborativa de conhecimento e de sociabilidade (Lemos, 2002).

O ciberespaço é o "hipertexto mundial interativo, onde cada um pode adicionar, retirar e modificar partes dessa estrutura telemática, como um texto vivo, um organismo auto-organizante"; é o "ambiente de circulação de discussões pluralistas, reforçando competências diferenciadas e aproveitando o caldo de conhecimento que é gerado dos laços comunitários, podendo potencializar a troca de competências, gerando a coletivização dos saberes"; é o ambiente que "não tem controle centralizado, multiplicando-se de forma anárquica e extensa, desordenadamente, a partir de conexões múltiplas e diferenciadas, permitindo agregações ordinárias, ponto a ponto, formando comunidades ordinárias" (Lemos, 2002, pp. 131-145/146).

Nesse contexto, o digital é responsável por uma revolução tecnológica e cultural sem precedentes, a partir da transformação de átomos em bits que dá origem à "vida digital" (Negroponte, 1996). A codificação digital contempla o caráter plástico, fluido, hipertextual, interativo e tratável em tempo real do conteúdo da mensagem. A transição do analógico para o digital permite a criação e estruturação de elementos de informação, as simulações, as formatações evolutivas nos ambientes online de informação e comunicação que permitem criar, gerir, organizar, fazer movimentar uma documentação completa com base em textos, imagens e sons.

Ao retirar a informação do mundo analógico - o mundo 'real', compreensível e palpável para os seres humanos - e transportá-la para o mundo digital, nós a tornamos infinitamente modificável. [...] Nós a transportamos para um meio que é infinita e facilmente manipulável. Estamos aptos a, de um só golpe, transformar a informação livremente - o que quer que ela represente no mundo real - de quase todas as maneiras que desejarmos e podemos fazê-lo rápida, simples e perfeitamente. [...]

Em particular, considero a significação da mídia digital sendo manipulável no ponto da transmissão porque ela sugere nada menos que um novo e sem precedente paradigma para a edição e distribuição na mídia. O fato de as mídias digitais serem manipuláveis no momento da transmissão significa algo realmente extraordinário: usuários da mídia podem dar forma a sua própria prática. Isso significa que informação manipulável pode ser informação interativa (Feldman, 1997, p 4).

Digital significa, portanto, uma nova materialidade das imagens, sons e textos que, na memória do computa- dor, são definidos matematicamente e processados por algoritmos, que são conjuntos de comandos como disposição para múltiplas formatações-intervenções-navegações operacionalizadas pelo computador. Uma vez que a imagem, o som e o texto, em sua forma digital, não têm existência material, podem ser entendidos como campos de possibilidades para a autoria dos interagentes. Isto é, por não terem materialidade fixa, podem ser manipulados infinitamente, dependendo unicamente de decisões que cada interagente toma ao lidar com seus periféricos de interação como mouse, tela tátil, joystick, teclado.

Há uma "geração digital" (Tapscott, 1999) transitando da tela da TV de massa para a tela do computador online, cujas disposições comunicacionais requerem das escolas e das universidades qualitativos investimentos na docência e na gestão da educação via Internet. Em particular, a educação online vive uma grandiosa oportunidade com o computador online que oferece disposições técnicas que contemplam a expressão de fundamentos essenciais da educação como diálogo, compartilhamento de informações e de opiniões, participação, autoria criativa e colaborativa.

As disposições técnicas conhecidas como fórum de discussão, chat, portfólio e blog podem ser facilmente instaladas ou disponibilizadas no ambiente da sala de aula online. São interfaces online ou espaços de encontro dos cursistas. Elas são capazes de ensejar a construção coletiva da comunicação e do conhecimento na Internet.

A disponibilização dos conteúdos de aprendizagem e das atividades de um curso via web precisará se dar conta de que pode potencializar a comunicação e a aprendizagem e não subutilizar as interfaces online que reúnem um conjunto de elementos de hardware e software destinados a possibilitar aos estudantes agregações, associações e significações como autoria e co-autoria. Pode integrar várias linguagens (sons, textos, imagens) na tela do computador online.

A partir de ícones e botões acionados por cliques no mouse, toques na tela ou combinação de teclas, janelas de comunicação se abrem possibilitando interatividade no chat, fórum, lista, blog e portfólio que podem estar reunidos como convergência de interfaces no ambiente online de aprendizagem.

Em suma, podemos dizer que o design de um curso pode lançar mão de proposições e de interfaces para a co-criação da comunicação e da aprendizagem em sua sala de aula online.

Disposições que deverão favorecer bidirecionalidade, sentimento de pertença, trocas, crítica e autocrítica, discussões temáticas, elaboração colaborativa, exploração, experimentação, simulação e descoberta.

Ou seja, para garantir qualidade em sua autoria, o professor precisará contar não apenas com o computador online, mas com o design de um curso capaz de favorecer a expressão do diálogo, do compartilhamento e da autoria criativa e colaborativa. 


\section{Sugestões para uma docência interativa presencial e online}

$\mathrm{Na}$ cibercultura os atores da comunicação tendem à interatividade e não mais à separação da emissão e recepção própria da mídia de massa. Para posicionar-se nesse contexto e aí educar, os professores precisarão dar-se conta do hipertexto, isto é, do não-seqüencial, da montagem de conexões em rede, que permite uma multiplicidade de recorrências entendidas como conectividade, diálogo e participação. Eles precisarão dar-se conta de que, de meros disparadores de lições-padrão, deverão se converter em formuladores de interrogações, coordenadores de equipes de trabalhos, sistematizadores de experiências.

\section{Mobilizar a experiência do conhecimento;}

Para operar com estas cinco sugestões para docência interativa, o professor deverá, por sua vez, garantir atitudes comunicacionais específicas:

- Acionar a participação-intervenção do receptor, sabendo que participar é muito mais que responder "sim" ou "não", é muito mais que escolher uma opção dada; participar é modificar, é interferir na mensagem (Silva, 2000). - Garantir a bidirecionalidade da emissão e recepção, sabendo que a comunicação é produção conjunta da emissão e da recepção; o emissor é receptor em potencial e o receptor é emissor em potencial; os dois pólos codifi-

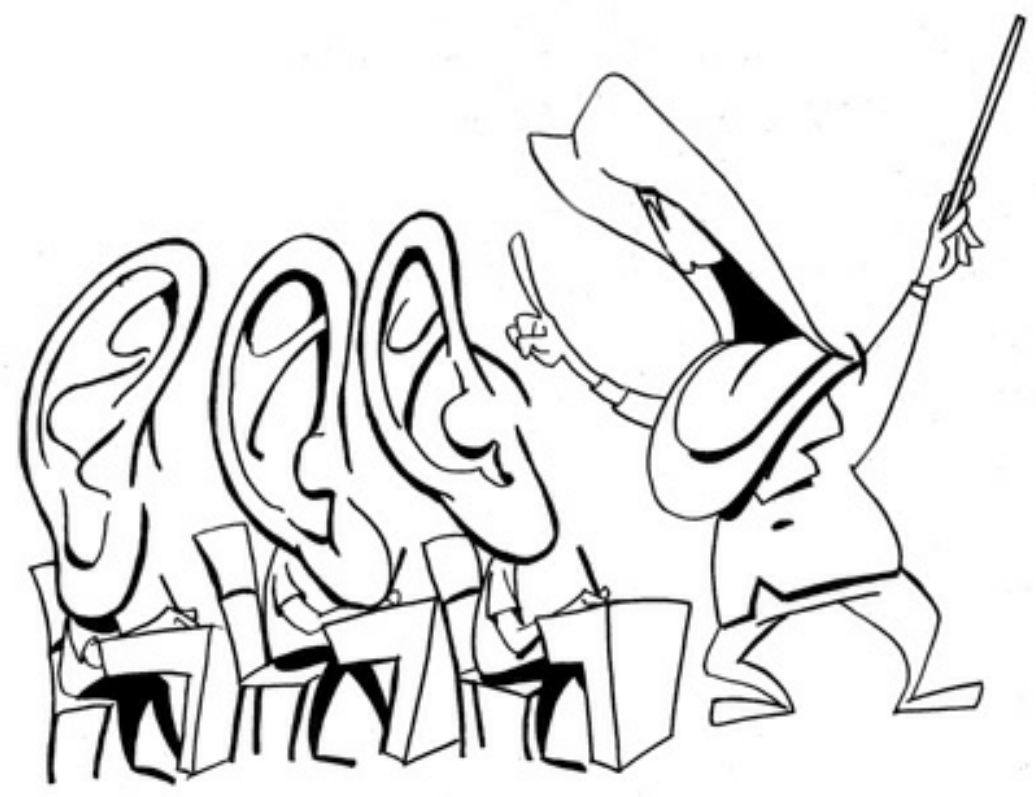

Docência unidirecional (modelo um-todos)

O docente propõe o conhecimento à maneira do hipertexto. Assim se redimensiona a sua autoria. Não mais a prevalência do falar-ditar, da distribuição de informação, mas a perspectiva da proposição complexa do conhecimento à participação colaborativa dos participantes, dos atores da comunicação e da aprendizagem.

O docente pode construir mediação interativa inspirada nas seguintes sugestões (Silva, 2005):

1. Propiciar oportunidades de múltiplas experimentações, múltiplas expressões;

2. Disponibilizar uma montagem de conexões em rede que permita múltiplas ocorrências;

\section{Provocar situações de inquietação criadora;}

4. Arquitetar colaborativamente percursos hipertextuais; cam e decodificam (Silva, 2000).

- Disponibilizar múltiplas redes articulatórias, sabendo que não se propõe uma mensagem fechada, ao contrário, oferecem-se informações em redes de conexões permitindo ao receptor ampla liberdade de associações, de significações (Silva, 2000).

- Engendrar a cooperação, sabendo que a comunicação e o conhecimento se constroem entre alunos e professor como co-criação (Silva, 2000).

- Suscitar a expressão e a confrontação das subjetividades no presencial e nas interfaces fórum, e-mail, chat, blog, wiki e portfolio, sabendo que a fala livre e plural supõe lidar com as diferenças na construção da tolerância e da democracia (Silva, 2003 e 2005).

- Garantir no ambiente online de aprendizagem uma riqueza de funcionalidades específicas tais como: intertextualidade (conexões com outros sites ou documentos), intratextualidade (conexões no mesmo documento), multivocalidade (multiplicidade de pontos de vista), usabilidade (percursos de fácil navegabilidade intuitiva), integração de várias linguagens (som, texto, ima 


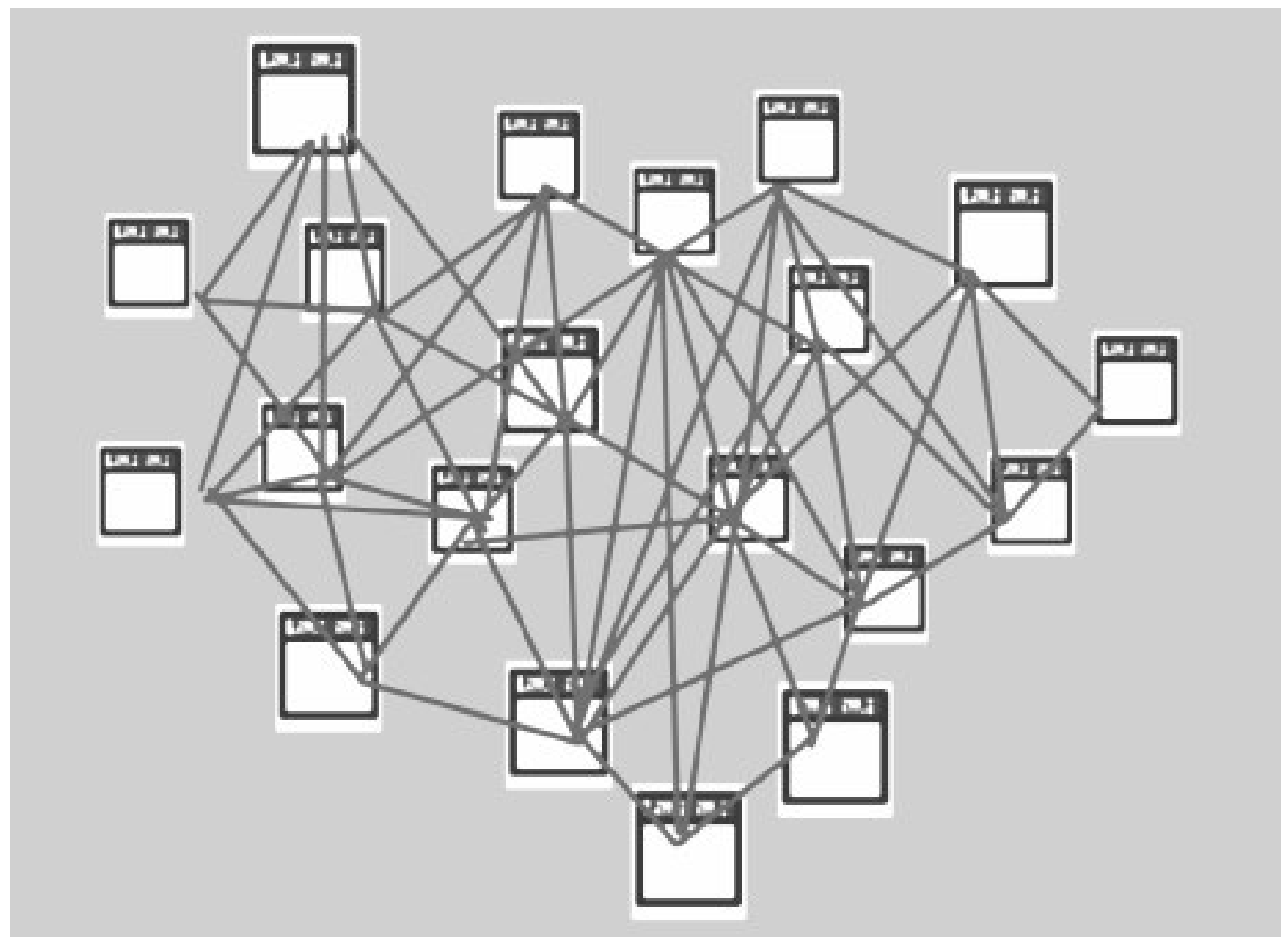

Docência interativa (modelo todos-todos)

gens dinâmicas e estáticas, gráficos, mapas), hipermídia (convergência de vários suportes midiáticos abertos a novos links e agregações) (Santos, 2003).

- Estimular a autoria cooperativa de formas, instrumentos e critérios de avaliação, criar e assegurar a ambiência favorável à avaliação formativa e promover avaliação contínua (Silva, 2006).

No ambiente comunicacional assim definido, estes princípios da docência interativa são linhas de agenciamentos que podem potencializar a autoria do professor, presencial e online. A partir de agenciamentos de comunicação capazes de contemplar o perfil comunicacional da geração digital que emerge com a cibercultura, $\mathrm{o}$ docente pode promover uma modificação paradigmática e qualitativa na sua docência e na pragmática da aprendizagem e, assim, reinventar a sala de aula em nosso tempo.

\section{Conclusão}

Este texto, fruto de pesquisas realizadas no PPGE da Universidade Estácio de Sá, vem mostrar que a educação via Internet vem se apresentando como grande desafio para o professor acostumado ao modelo clássico de ensino. São dois universos distintos no que se refere ao paradigma comunicacional dominante em cada um. Enquanto a sala de aula tradicional está vinculada ao modelo unidirecional "um-todos", que separa emissão ativa e recepção passiva, a online está inserida na perspectiva da dinâmica comunicacional da cibercultura entendida aqui como colaboração "todos-todos" e como "'faça você mesmo" operativo.
Acostumado ao modelo da transmissão de conhecimentos prontos, o professor se sente pouco à vontade no ambiente digital que libera a participação dos aprendizes como co-autores da comunicação e da aprendizagem.

Prevalece, ainda hoje, o modelo tradicional de educação baseado na transmissão para memorização, ou na distribuição de pacotes fechados de informações ditos "conhecimentos". Há cinco mil anos a escola está baseada no falar-ditar do mestre e na repetição. Não é fácil sair desse paradigma para a interatividade, a não ser violentando a natureza comunicacional da nova mídia, repetindo o que faz na sala presencial.

No ambiente online o professor terá que modificar sua velha postura, inclusive para não subutilizar a interatividade própria do meio. No lugar da memorização e da transmissão, o professor propõe a aprendizagem modelando os domínios do conhecimento como espaços abertos à navegação, colaboração e criação. Ele propõe o conhecimento em teias (hipertexto) de ligações e de interações permitindo que os alunos conduzam suas explorações.

De apresentador que separa palco e platéia, o professor passa a arquiteto de percursos, mobilizador das inteligências múltiplas e coletivas na experiência da cocriação do saber. E o aluno, por sua vez, deixa a condição de espectador, não está mais submetido ao constrangimento da recepção passiva, reduzido a olhar, copiar e prestar contas.

Assim, ele cria, modifica, constrói e torna-se co-autor da aprendizagem. 


\section{É preciso se colocar a par da cibercultura, isto é, da atualidade sociotécnica informacional e comunicacional definida pela codificação digital (bits), pela digitalização que garante 0 caráter plástico, hipertextual, interativo e tratável em tempo real do conteúdo.}

Para não violentar esse aluno nem a Internet, o professor precisa aprender com o webdesigner e não mais com o apresentador de TV. Enquanto esse velho conhecido é o narrador que atrai o espectador de maneira sedutora para sua récita, o informata constrói uma teia de territórios abertos a navegações e dispostos a interferências. $\mathrm{O}$ professor precisa perceber que a tela da TV é espaço de irradiação que só permite mudar de canal, enquanto a do computador é tridimensional e permite adentramento e manipulação dos conteúdos. Precisa perceber, enfim, que a TV é para assistir e o computador, para interagir. Assim emerge uma nova ambiência comunicacional - a cibercultura.

É preciso se colocar a par da cibercultura, isto é, da atualidade sociotécnica informacional e comunicacional definida pela codificação digital (bits), isto é, pela digitalização que garante o caráter plástico, hipertextual, interativo e tratável em tempo real do conteúdo. A codificação digital permite manipulação de documentos, criação e estruturação de elementos de informação, simulações, formatações evolutivas nos ambientes ou estações de trabalho concebidas para criar, gerir, organizar e movimentar uma documentação.

O professor pode lançar mão dessa disposição do digital para potencializar sua sala de aula online. Ao fazê-lo, ele contempla atitudes cognitivas e modos de pensamento que se desenvolvem juntamente com o crescimento da cibercultura. Ou seja, contempla o novo espectador, a geração digital e, curiosamente, a qualidade em educação efetiva, isto é, que supõe participação, compartilhamento e colaboração.

Por não perceber a nova ambiência comunicacional que emerge com a cibercultura, o professor tenderá a manter em seus cursos via Internet o mesmo modelo de ensino em que os conteúdos são distribuídos em sites educacionais estáticos, ainda centrados na transmissão de dados, desprovidos de mecanismos de interatividade e de criação coletiva. Em suma, este texto procurou mostrar que a emergência da cibercultura vem corroborar a crítica já existente na teoria da educação que diz: o professor é o responsável pela produção e transmissão do conhecimento; os cursos pela Internet acabam considerando que as pessoas são recipientes de informação; a educação continua a ser, mesmo na tela do computador conectado em banda larga, repetição burocrática, transmissão de conteúdos empacotados; se não muda o paradigma, a Internet acaba servindo para reafirmar o que já se faz afamecos

\section{REFERÊNCIAS}

COUCHOT, E. A arte pode ainda ser um relógio que adianta? $\mathrm{O}$ autor, a obra e o espectador na hora do tempo real. In: A arte no século XXI: a humanização das tecnologias. DOMINGUES, D. (org.). São Paulo: FAPESP, 1997

FELDMAN, T. Introduction to digital media. New York/ London: Routledge, 1997.

LEMOS, A. Cultura das redes: Ciberensaios para o século XXI. Salvador: EDUFBA, 2002.

\section{LÉVY, P. Cibercultura. São Paulo: Ed. 34, 1999.}

MARCHAND, M. Les paradis informationnels: du Minitel aux services de communication du futur. Paris: Masson, 1987.

NEGROPONTE, N. A vida digital. São Paulo: Cia. das Letras, 1996.

SANTOS, E. O. Articulação de saberes na EAD online: por uma rede interdisciplinar e interativa de conhecimentos em ambientes virtuais de aprendizagem. In: SILVA, M. (Org.).Educação online. São Paulo: Loyola, 2003.

SILVA, M. Sala de aula interativa. Rio de Janeiro: Quartet, 2000.

Criar e professorar um curso online. In: SILVA, M. (Org.) Educação online. São Paulo: Loyola, 2003.

Educación interactiva: enseñanza y aprendizaje presencial y on-line. Madrid: Gedisa, 2005.

O fundamento comunicacional da avaliação da aprendizagem na sala de aula online. In: SILVA, M.; SANTOS, E. O. (Orgs.). Avaliação da aprendizagem em educação online. São Paulo: Loyola, 2006.

TAPSCOTT, D. Geração digital: a crescente e irredutível ascensão da geração net. Trad. Ruth Bahr. São Paulo: MAKRON Books, 1999. 